\title{
EFFECT OF RESULTS AND INFLATION ON THIRD PARTY FUNDS IN SHARIA COMMERCIAL BANKS AND SHARIA BUSINESS UNITS INFLUENCE OF RESULTS AND INFLATION ON THIRD PARTY FUNDS IN SHARIA COMMERCIAL BANKS AND SHARIA BUSINESS UNITS
}

\author{
Rizka $^{1}$, Azwar Hamid $^{2}$, Ihdi Aini ${ }^{3}$, Sulaiman ${ }^{4}$ \\ ${ }^{1}$ IAIN Padangsidimpuan (Perbankan Syariah, FEBI, IAIN Padangsidimpuan) \\ ${ }^{2}$ IAIN Padangsidimpuan (Perbankan Syariah, FEBI, IAIN Padangsidimpuan) \\ ${ }^{3}$ IAIN Padangsidimpuan (Perbankan Syariah, FEBI, IAIN Padangsidimpuan) \\ ${ }^{4}$ IAIN Padangsidimpuan (Perbankan Syariah, FEBI, IAIN Padangsidimpuan) \\ Elnasriwanna@gmail.com ${ }^{1}$, Azwar@iain-padangsidimpuan.ac.id $^{2}$, Ihdi@iain-padangsidimpuan.ac.id $^{3}$ \\ sulaiman@iain-padangsidimpuan.ac.id ${ }^{4}$
}

\begin{abstract}
ABSTRAK
Dana pihak ketiga adalah penghimpun dana yang ada dalam perbankan. Dana pihak ketiga meliputi giro, tabungan dan deposito yang dihimpun dari masyarakat. Dana pihak ketiga selalu menalami kenaikan tetapi tidak diikuti oleh bagi hasil dan inflasi yang mengalami fluktuasi. Rumusan masalah dalam penelitian ini adalah Apakah bagi hasil dan inflasi berpengaruh secara parsial dan simultan terhadap Dana Pihak Ketiga pada Bank Umum Syariah Dan Unit Usaha Syariah. Tujuan penelitian ini untuk mengetahui seberapa besar pengaruh bagi hasil dan inflasi terhadap Dana Pihak Ketiga pada Bank Umum Syariah Dan Unit Usaha Syariah. Pembahasan dalam penelitian ini berkaitan dengan ilmu perbankan syariah dan ekonomi makro. Pendekatan yang dilakukan dalam penelitian ini berhubungan dengan teori-teori yang berkaitan dengan bagi hasil, inflasi dan Dana Pihak Ketiga. Penelitian ini adalah penelitian kuantitatif, sumber data adalah sekunder dengan bentuk times series sebanyak 72 sampel. Tekhnik pengumpulan data adalah dokumentasi dan kepustakaan. Uji normalitas, Uji normalitas, Uji Asumsi Klasik yang meliputi Uji Multikoliniaritas, Uji Autokorelasi, Uji Heteroskedastisitas, Uji Hipotesis yang meliputi Uji Signifikan Parsial (Uji t), Uji Koefisien Regresi Secara Simultan (Uji F), Uji Koefisien Determinasi, Analisis Linier Berganda. Hasil penelitian ini menunjukkan bahwa secara parsial bagi hasil memiliki - $t_{\text {hitung }}<$ $t_{\text {tabel }}(-2,725<-1,667)$ yang artinya bagi hasil berpengaruh negatif signifikan terhadap DPK. Dan inflasi memiliki $-t_{\text {hitung }}<-t_{\text {tabel }}(-4,852<-1,667)$ yang artinya inflasi berpengaruh signifikan negatif terhadap Dana Pihak Ketiga. Serta bagi hasil dan inflasi secara simultan berpengaruh terhadap Dana Pihak Ketiga. Hal tersebut dibuktikan dengan nilai $F_{\text {hitung }}>F_{\text {tabel }}(48,966>3,13)$. $\mathrm{R}^{2}$ menunjukkan bahwa persentase sumbangan pengaruh variabel independen terhadap variabel dependen sebesar $58,7 \%$ dan sisanya sebesar $41,3 \%$ dipengaruhi atau atau dijelaskan oleh variabel lain yang tidak dimasukkan dalam model penelitian ini.
\end{abstract}

Kata Kunci: Dana Pihak Ketiga, Bagi Hasil, Inflasi

\section{ABSTRACT}

Third-party funds are fund collectors in the banking sector. Third party funds include current accounts, savings and deposits collected from the community. Third party funds always experience an increase but are not followed by revenue sharing and inflation that has fluctuated. The formulation of the problem in this study is whether the profit sharing and 
inflation have a partial and simultaneous effect on Third Party Funds in Sharia Commercial Banks and Sharia Business Units. The purpose of this study was to determine how much the effect of profit sharing and inflation on Third Party Funds in Sharia Commercial Banks and Sharia Business Units. The discussion in this study relates to Islamic banking and macroeconomics. The approach taken in this study relates to theories relating to revenue sharing, inflation and Third Party Funds. This research is a quantitative study, the source of the data is secondary with a series of times series of 72 samples. Data collection techniques are documentation and literature. Normality Test, Normality Test, Classical Assumption Test which includes Multicollinearity Test, Autocorrelation Test, Heteroscedasticity Test, Hypothesis Test which includes Partial Significant Test $\left(t_{\text {Test }}\right)$, Simultaneous Regression Coefficient Test $\left(\mathrm{F}_{\text {test }}\right)$, Determination Coefficient Test, Multiple Linear Analysis. The results of this study indicate that partially the shares have $-t_{\text {test }}<t_{\text {table }}(-2.725<-1.667)$ which means that the results have a significant negative effect on DPK. And inflation has $-t_{\text {test }}<-t_{\text {table }}(-4,852<-$ $1,667)$ which means that inflation has a significant negative effect on Third Party Funds. And profit sharing and inflation simultaneously affect the Third Party Fund. This is evidenced by the value of $F_{\text {count }}>F_{\text {table }}(48.966>3.13)$. $R^{2}$ shows that the percentage of contribution of the influence of independent variables on the dependent variable is $58.7 \%$ and the remaining $41.3 \%$ is influenced or or explained by other variables not included in this research model.

Keywords: Third Party Funds, Revenue Share, Inflation

\section{A. PENDAhUluAN}

Bank syariah merupakan suatu lembaga keuangan yang beroperasi berdasarkan prinsip sesuai syariah Islam. Dalam melaksanakan semua kegiatan usaha antara bank dan nasabah harus berlandaskan pada aturan perjanjian (akad) yang sesuai dengan prinsip syariah. Bank syariah adalah sistem perbankan yang memiliki karateristik sendiri yaitu sistem yang operasional yang menerapkan bagi hasil dan produknya harus halal, jauh dari riba, ketidakpastian dan penipuan. (Ridwan Nurdin, 2010: 24).
Tahun 1999 berdirilah Bank Syariah Mandiri yang menjadi petaruhan bagi bankir syariah. Bank Syariah Mandiri berhasil, maka Bank Syariah Mandiri di Indonesia dapat berkembang. Menurut jenisnya bank syariah ada tiga yaitu Bank Umum Syariah (BUS), Unit Usaha Syariah (UUS), dan Bank Pembiayaan Rakyat Syariah (BPRS). (Sutan Remy Sjahdeiny, 2014: 102).

Bank syariah yang terdiri dari BUS, UUS, BPRS, pada dasarnya melakukan kegiatan usaha yang sama dengan bank konvensional, yaitu melakukan penghimpunan dan penyaluran dana masyarakat di samping penyediaan jasa 
keuangan lainnya. Perbedaannya adalah seluruh kegiatan Usaha Bank Syariah, UUS dan BPRS didasarkan pada prinsip syariah. Implikasinya, di samping harus selalu sesuai dengan prinsip hukum Islam juga adalah karena dalam prinsip syariah memiliki berbagai variasi akad yang akan menimbulkan variasi produk yang lebih banyak di bandingkan produk konvensional. (Andri Soemitra, 2009: 72).

Dari beberapa penelitian terdahulu dapat diketahui bahwa pengaruh bagi hasil dan inflasi tidak konsisten, ada yang berpengaruh negatif ada juga yang berpengaruh positif terhadap Dana Pihak Ketiga. Seperti pada penelitian Aldrin Wibowo dan Susi Suhendra yang berjudul Analisis Pengruh Nilai Kurs, Tingkat Inflasi, Dan Tingkat Suku Bunga Terhadap Dana Pihak Ketiga Pada Bank Devisa Di Indinesia (Periode Triwulan I 2003-Triwulan III 2008. Hasil dari penelitian ini adalah secara persial variabel KURS dan inflasi memiliki pengaruh positif sedangkan suku bunga berpengaruh negatif terhadap dana pihak ketiga sedangkan secara simultan nilai kurs, tingkat inflasi, dan tingkat suku berpengaruh
POINT Vol. 2, No. 1, Jul 2021 positif terhadap dana pihak ketiga pada bank devisa di Indonesia.

Sedangkan penelitian menurut penelitian Hermanto, dalam penelitiannya Faktor- Faktor Yang Mempengaruhi Dana Pihak Ketiga Pada Bank Umum Syariah Tahun 20052007 menyatakan bahwa Suku bunga berpengaruh secara negatif dan signifikan terhadap Dana Pihak Ketiga (DPK), bagi hasil berpengaruh positif secara signifikan terhadap Dana Pihak Ketiga (DPK). PDB tidak berpengaruh terhadap dana pihak ketiga (DPK), inflasi tidak berpengaruh terhadap Dana Pihak Ketiga (DPK).

Sedangkan dalam penelitian Ferdiansyah, dalam penelitiannya Pengaruh Rate Bagi Hasil Dan Bi Rate Terhadap Dana Pihak Ketiga Perbankan Syariah (Studi Pada Bank Pembiayaan Rakyat Syariah Yang Terdaftard di Bank Indonesia) menyatakan bahwa bahwa secara persial variabel Rate Bagi Hasil Dan Bi Rate secara parsial mempunyai pengaruh yang signifikan terhadap dana pihak ketiga dan Dan Bi Rate mempunyai pengaruh negatif yang signifikan terhadap dana pihak ketiga. Secara simultan tingkat imbalan dan 
bagi hasil berpengaruh terhadap DPK Pada Bank

Pembiayaan Rakyat Syariah. Dan dalam penelitian Honinah, dalam penelitiannya yang berjudul Pengaruh Tingkat Imbalan dan Inflasi terhadap Dana Pihak Ketiga pada Bank Umum Syariah dan Unit Usaha Syariah Di Indonesia Tahun 2013-2016. Menyatakan bahwa secara persial variabel tingkat imbalan secara parsial tidak mempunyai pengaruh yang signifikan terhadap DPK, sedangkan inflasi mempunyai pengaruh negatif yang signifikan terhadap DPK. Secara simultan tingkat imbalan dan bagi hasil berpengaruh terhadap DPK pada BUS dan UUS di Indonesia.

Dalam penelitian Nisa lidya muliawati dan tatik maryati, dalam penelitiannya yang berjudul Analisis Pengaruh Inflasi, Kurs, Suku Bunga dan Bagi Hasil Terhadap Deposito Pada PT. Bank Mandiri Syariah 2007-2012. Menyatakan bahwa Variabel inflasi tidak berpengaruh signifikan terhadap deposito mudharabah. Variabel nilai tukar memiliki efek negatif yang signifikan terhadap deposito mudharabah. Variabel $\mathrm{BI}$ rate berpengaruh negtif dan tidak signifikaan terhadap deposito mudharabah. Sedangkan variabel bagi hasil memiliki pengaruh signifikan terhadap deposito mudharabah.

Dari beberapa hasil penelitian terdahulu dapat dilihat bahwa pengaruh bagi hasil dan inflasi tidak konsisten, ada yang menyatakan berpengaruh negatif ada juga yang berpengharuh positif.

Berdasarkan latar belakang diatas peneliti tertarik melakukan penelitian dengan judul "Pengaruh Bagi Hasil Dan Inflasi Terhadap Dana Pihak Ketiga Pada Bank Umum Syariah (BUS) Dan Unit Usaha Syariah (UUS).

\section{B. METODE}

1. Lokasi dan Waktu Penelitian Lokasi penelitian dilakukan pada Bank Umum Syariah (BUS) dan Unit Usaha Syariah (UUS) seluruh Indonesia melalui situs resmi Otoritas Jasa Keuangan (www.ojk.go.id) dan situs resmi Bank Indonesia (www.bi.go.id). Waktu penelitian ini adalah mulai dari November 2018 sampai dengan selesai.

\section{Jenis Penelitian}

Dalam penelitian ini menggunakan data kuantitatif. Penelitian kuantitatif merupakan penelitian yang menjelaskan hubungan atau pengaruh yang terukur, meramalkan dan 
mengontrol. Penelitian ini menggunakan

pendekatan kuantitatif berdasarkan runtut waktu (time series). Data runtut waktu (time series) merupakan data yang secara kronologis disusun menurut waktu pada suatu variabel tertentu dan digunakan untuk melihat pengaruh perubahan dalam rentang waktu tertentu. (Mudrajat Kuncoro, 2009: 16)

\section{Populasi dan sampel}

a. Populasi

Menurut Husein Umar " populasi adalah wilayah generalisasi yang terdiri atas obyek maupun subyek yang mempunyai kualitas dan karateristik tertentu yang ditetapkan oleh peneliti untuk dipelajari dan kemudian ditarik kesimpulannya. (Sugiono, 2016: 80)

b. Sampel

Sampel adalah bagian dari jumlah dan karateristik yang dimiliki oleh populasi tersebut. Bila populasi besar, dan peneliti tidak mungkin mempelajari semua yang ada pada populasi, misalnya karena keterbatasan dana, tenaga dan waktu, maka peneliti dapat menggunakan sampel yang diambil dari populasi. (Sugiono, 2005: 72)
4. Sumber Data

POINT Vol. 2, No. 1, Jul 2021

Penelitian ini menggunakan data sekunder, yaitu data yang telah dikumpulkan oleh pihak lain. Peneliti dapat mencari data sekunder ini melalui sumber data sekunder.

5. Pengumpulan Data

Adapun teknik pengumpulan data yang dapat diperoleh pada penelitian ini dengan dokumentasi. Dokumentasi adalah mencari data mengenai hal-hal atau variabel yang berupa catatan, transkip, buku, surat kabar, majalah dan sebagainya. Dalam melaksanakan metode dokumentasi, peneliti menyelidiki benda-benda tertulis seperti buku-buku, majalah, dokumen, dan catatan

\section{HASIL DAN PEMBAHASAN}

1. Pengaruh Bagi Hasil Terhadap Dana Pihak Ketiga Pada Bank Umum Syariah Dan Unit Usaha Syariah

Berdasarkan hasil penelitian spss versi 22, maka diperoleh hasil nilai thitung sebesar $-2,725$, jadi hasil untuk $t$ tabel adalah -1,667 maka thitung < ttabel $(-2,725<-1,667)$. Maka Ho ditolak dan Ha1 diterima. Jadi disimpulkan bahwa bagi hasil secara parsial berpengaruh negatif tidak signifikan terhadap DPK pada Bank Umum Syariah dan Unit Usaha Syariah. 
Hasil penelitian ini juga sejalan

dengan penelitian Hermanto, yang

berjudul "Faktor- Faktor Yang

Mempengaruhi Dana Pihak Ketiga Pada

Bank Umum Syariah Tahun 2005- 2007"

yang menyatakan bahwa bagi hasil

berpengaruh negatif secara signifikan

terhadap Dana Pihak Ketiga (DPK).

Hasil penelitian ini sejalan dengan buku stategi sukses bisnis bank modul sertifikasi tingkat III general banking Indonesia, jika tinggi imbalan/ bagi hasil yang di berikan bank maka masyarakat akan tertarik unttuk menabung dananya di bank syariah. Masyarakat yang menempatkan dananya di bank syariah sebagian besar karena melihat pada nilai imbalan/ bagi hasil yang akan diterima pada bulan atau tahun sebelumnya jika nilainya besar maka masyarakat akan semakin berkeinginan besar untuk menabung di bank syariah begitu juga sebaliknya jika imbalan/ bagi hasil kecil maka msyarakat akan semakin sedikit yang berkeinginan menabung di bank syariah.

2. Pengaruh Inflasi Terhadap Dana Pihak Ketiga Pada Bank Umum Syariah Dan Unit Usaha Syariah

Berdasarkan hasil penelitian spss versi 22, maka diperoleh hasil nilai thitung sebesar $-4,852$ ttabel adalah $-1,667$ maka thitung $>$ ttabel $(-4,852<1,667)$. Maka Ho ditolak dan Ha diterima. Jadi disimpulankan bahwa inflasi secara parsial berpengaruh negatif signifikan terhada DPK pada Bank Umum Syariah dan Unit Usaha Syariah.

Hasil penelitian ini juga sejalan dengan penelitian honinah, dengan judul "Pengaruh Tingkat Imbalan dan Inflasi terhadap Dana Pihak Ketiga pada Bank Umum Syariah dan Unit Usaha Syariah Di Indonesia Tahun 2013-2016" yang menyatakan variabel NBH tidak mempunyai pengaruh yang signifikan terhadap Dana Pihak Ketiga (DPK) perbankan syariah di indonesia.

Hasil penelitian ini juga sejaln dengan teori aulia pohan dalam bukunya potret kebijakan moneter yaitu adanya ekspektasi masyarakat tentang melemahnya nilai rupiah dapat mengakibatkan berkurangnya kepercayaan masyarakat terhadap rupiah. Keadaan ini akan mengakibatkan berkurangnya kesetersediaan dana masyarakat yang dapat dihimpun oleh perbankan untuk disalurkan ke sektor yang produktif.

3. Pengaruh Bagi Hasil dan Inflasi Terhadap Dana Pihak Ketiga pada Bank Umum Syariah dan Unit Usaha Syariah

Dalam penelitian ini jika variabel independen di uji secara simultan terhadap variabel dependen. Maka diperoleh hasil dengan nilai Fhitung sebesar 48,966 untuk Ftabel sebesar 3,13. Hasil analisis dari data uji F menunjukkan bahwa Fhitung $\geq$ Ftabel $=48,966 \geq 3,13$, jadi dapat disimpulkan 
bawa bagi hasil dan inflasi secara simultan berpengaruh signifikan terhadap DPK pada Bank Umum Syariah dan Unit Usaha Syariah yaitu sebesar $58,7 \%$ dengan sisa $41,3 \%$ dipengaruhi oleh variabel lain yang tidak dimasukkan dalam penelitian ini, dalam arti lain bahwa masih ada variabel independen lain yang mempengaruhi DPK.

Dan juga menurut penelitian Honinah dengan judul "Pengaruh Tingkat Imbalan dan Inflasi terhadap Dana Pihak Ketiga pada Bank Umum Syariah dan Unit Usaha Syariah Di Indonesia Tahun 2013-2016" yang menyatakan yang menyatakan bahwa tingkat imbalan dan inflasi memiliki berpengaruh positif terhadap Dana Pihak Ketiga pada Bank Umum Syariah (BUS) dan Unit Usaha Syariah (UUS).

\section{PENUTUP}

1. Kesimpulan

Berdasarkan hasil pengelolahan data dari penelitian yang berjudul " pengaruh bagi hasil dan inflasi terhadap Dana Pihak Ketiga pada Bank Umum Syariah dan Unit Usaha Syariah dapat diambil kesimpulan sebagai berikut:

- Berdasarkan uji parsial (uji-t) pada bagi hasil diperoleh hasil nilai thitung sebesar 2,725 , jadi hasil untuk ttabel adalah $-1,667$ maka thitung $>$ ttabel $(-2,725<-1,667)$ Artinya Ho ditolak dan Ha diterima. Maka kesimpulan dari uji parsial (uji t) bahwa bagi hasil mempunyai pengaruh negatif
POINT Vol. 2, No. 1, Jul 2021 signifikan terhadap DPK pada Bank Umum Syariah dan Unit Usaha Syariah.

- Berdasarkan uji parsial (uji-t) pada inflasi diperoleh hasil nilai thitung sebesar $-4,852$ ttabel adalah -1,667 maka thitung > ttabel $(-4,852<-1,667)$. Artinya Ho ditolak dan Ha diterima. Maka kesimpulan dari uji parsial (uji t) bahwa bagi hasil mempunyai pengaruh negatif yang signifikan terhadap DPK pada Bank Umum Syariah dan Unit Usaha Syariah.

- Berdasarkan hasil uji simultan (uji F) diperoleh hasil dengan nilai Fhitung sebesar 48,966 untuk Ftabel sebesar 3,13. Hasil analisis dari data uji F menunjukkan bahwa Fhitung $\geq$ Ftabel $=48,966 \geq 3,13$, maka dapat disimpilkan $\mathrm{Ho}$ ditolak dan $\mathrm{Ha}$ diterima. Artinya bagi hasil dan inflasi berpengaruh secara simultan terhadap Dana Pihak Ketiga pada BUS dan UUS di Indonesia.

\section{Saran}

Semoga adanya pengetahuan masyarakat terhadap minat produk perbankan syariah

\section{DAFTAR PUSTAKA}

Adi Warman A Karim, Bank Islam Analisis Fiqih Dan Keuangan, Jakarta: PT Raja Grapindo Persada, 2004

Andri Soemitra, Bank dan Lembaga Keuangan Syariah, Jakarta: Kencana, 2009 
Aulia Pohan, Potret Kebijakan Moneter Indonesia, Jakarta: PT Raja Grafindo, 2008

Sadono Sukirno, Makro Ekonomi Teori Pengantar Jakarta: PT Raja Grafindo Persada, 2004

Ismail, Manajemen Perbankan, Jakarta: Kencana, 2010

Sugiono, Metode Penelitian Bisnis, Bandung: Alfabeta, 2005

Khaerul Umam, Manajemen Perbankan Syariah, Bandung: Pustaka Setia, 2013

Muhammad Syafi'i Antonio, Bank Syariah Dari Teori Ke Praktik Jakarta: Gema Insani, 2001

R. Serfianto D. Purnomo, Cita Yustisia Serfiani, Iswi Hariani, Pasar Uang Dan Pasar Valas, Jakarta: PT Gramedia Pustaka Utama, 2013

Ridwan Nurdin, Akad-Akad Fiqih pada Perbankan Syariah (Sejarah Konsep dan Perkembangannya), Banda Aceh: Pena, 2010

, Metode Penelitian Kuantitatif, Kualitatif, R\&D, Bandung: Alfabeta, 2016

Sutan Remy Sjahdeiny, Perbankan Syariah: Produk-Produk dan Aspek-Aspek Hukumnya, Jakarta: Kencana, 2014

Veithzal Rivai, Islamic Financial Management, Jakarta: PT. Raja Grafindo Persada, 2007 